УДК 634.0.813

\title{
ИЗУЧЕНИЕ СОДЕРЖАНИЯ ФИТОСТЕРИНОВ В АНАТОМИЧЕСКИХ ЧАСТЯХ БОЯРЫШНИКА КРОВАВО-КРАСНОГО
}

\author{
() А.Н. Девятловская ${ }^{1 *}$, Л.Н. Журавлёва ${ }^{1}$, Ю.Д. Алаикевич ${ }^{2}$ \\ ${ }^{1}$ Лесосибирский фрилиал Сибирского государственного технологического \\ университета, ул. Победы, 29, Лесосибирск, 662543 (Россия), \\ e-mail:devyatlovskiy@mail.ru \\ ${ }^{2}$ Сибирский государственный технологический университет, пр. Мира, 82, \\ Красноярск, 660049 (Россия), e-mail: mapt@sibstu.kts.ru
}

В работе изучена годичная динамика содержания свободных и связанных стеринов в анатомических частях боярышника кроваво-красного. Установлены содержание и состав жирных кислот связанных стеринов в побегах и плодах в ходе годового цикла. кислота.

Ключевые слова: стерины, гликозиды, годовой цикл, жирные кислоты, стеариновая кислота, пальмитиновая

\section{Введение}

К липидам относится большое число природных веществ, разнообразных по химическому составу и структуре, обладающих общими свойствами: нерастворимостью в воде, способностью растворяться в органических растворителях, важностью функций в живых организмах [1]. Липиды являются интегральными компонентами клеточных мембран. Среди этих групп липидов важное место занимают стерины. Стерины входят в состав клеточных мембран, локализуются во внутриклеточных органеллах и совместно с фосфолипидами стабилизируют мембраны и контролируют их проницаемость [2].

В растениях стерины в больших количествах обнаруживаются в тех органах и тканях, которые интенсивно функционируют и содержат большое число делящихся клеток: меристема, хлоропласты, семена [2]. Важными представителями растительных стеролов являются ситостерин, стигмастерин, брассикастерин, кампестерин и их эфиры. Кроме этих стеринов, в растениях обнаружены сквален, циклоартенол, цитростадиенол. Основным компонентом группы стероидов в древесине хвойных пород является $\beta$-ситостерин [3].

Природные стерины являются сырьем для синтеза стероидных гормонов. Так, из стигмастерина и эргостерина можно получить прогестерон, а из холестерина и $\beta$-ситостерина - ацетат дегидроэпиандростерина - полупроводников стероидных гормонов.

Боярышник кроваво-красный содержит комплекс биологически активных соединений и может быть

Девятловская Анна Николаевна - заведующая кафедрой фундаментальной подготовки, кандидат технических наук, доцент, тел.: (39145) 6-28-03, e-mail: devyatlovskiy@mail.ru

Журавлёва Людмила Николаевна - заведующая кафедрой технологии производств в лесном комплексе, кандидат технических наук, доцент, тел.: (39145) 6-28-03, e-mail: e-mail: tplk.ln@yandex.ru Алашкевич Юрий Давыдович - заведующий кафедрой машин и аппаратов промышленных технологий, доктор технических наук, профессор, тел.: (391) 227-34-53, e-mail:mapt@sibstu.kts.ru использован в производстве продуктов лечебнопрофилактической направленности. Изучение фитостеринов в боярышнике позволит рационально и полно использовать природные растительные ресурсы, стимулировать создание безотходной и малоотходной технологии, которая является экологической и природоохранной.

Боярышник кроваво-красный растет в лесной, лесостепной зоне, на опушках и на полянах. Более обилен в лесостепной зоне, по речным поймам. Он

\footnotetext{
* Автор, с которым следует вести переписку.
} 
является неприхотливым, морозостойким растением, предпочитает песчано-галечниковые аллювиальные почвы, но не переносит близкого залегания уровня грунтовых вод и подтопления. Цветет в течение десяти дней обильно в начале лета после распускания листьев. Плоды боярышника достаточно крупные, краснобурой окраски, держатся на растении до двух месяцев.

Цель настоящего исследования - изучение содержания стеринов в анатомических частях боярышника кроваво-красного и определение содержания состава жирных кислот связанных стеринов в побегах в ходе годового цикла.

\section{Экспериментальная часть}

В качестве исходного сырья использовали различные ткани боярышника кроваво-красного (Crataegus sangunea Pall.), заготовленного на территории Енисейского района Красноярского края. Биологический материал отбирали из средних ярусов, произрастающих на одном участке в одинаковых условиях. Листья, плоды и цветки заготавливали в сухую солнечную погоду, так как после росы и дождя они темнеют. Цветки собирали в начале цветения, пока они не все раскрылись, срезая щитковидные соцветия и отдельные цветки. Сушили не позже чем через 2 ч после сбора при температуре $70{ }^{\circ} \mathrm{C}$.

Состав стеринов заметно меняется в зависимости от вида растения, его возраста, времени года, температуры и других факторов. Проведение данных исследований невозможно без установления представительности проб, которые бы обеспечивали необходимую достоверность полученных результатов. Так как содержание стеринов в побегах небольшое, были взяты пробы с 20 деревьев боярышника кровавокрасного. С помощью методов математической статистики определены статистические характеристики содержания стеринов в побегах и рассчитан размер выборки. Из полученных данных следует: чтобы с вероятностью 95\% определить содержание стеринов в побегах боярышника, произрастающих в одинаковых условиях, отклоняющихся от среднего значения не более чем на $5 \%$, необходимо исследовать не менее 16 деревьев.

Липиды представляют собой сложную смесь веществ, относящихся к различным классам соединений. Общую липидную фракцию извлекали из анализируемых растительных тканей по методу Блайя и Дайера смесью растворителей хлороформ - изопропиловый спирт. Суммарные липиды использовали для выделения нейтральных липидов и гликолипидов.

Свободные стерины и эфиры стеринов выделяли из нейтральных липидов методом тонкослойной хроматографии на силикагеле в системе растворителей гексан - диэтиловый эфир - уксусная кислота $(85: 15: 1)$. Хроматограмму обрабатывали специфическими обнаружителями и нагревали при температуре $80{ }^{\circ} \mathrm{C}$. Чистоту полученных веществ определяли методом микротонкослойной хроматографии [1].

Количественную оценку содержания стеринов в полученных пробах проводили методами Amenta, Либермана - Бурхарда и Златкиса - Зака в модификации Кваифа [1]. Пользуясь методом Златкиса - Зака к пробе прибавляли раствор гексагидрата хлорида железа (III) в уксусной кислоте. Смесь выдерживали 30 мин при комнатной температуре для развития окраски.

Выделение гликолипидов стеринов для анализа осуществляли с помощью метода тонкослойной хроматографии. Исследуемый экстракт гликолипидов подвергали двумерной хроматографии. Для хроматографического разделения гликолипидов использовали системы: 1-е направление - ацетон - толуол - уксусная кислота - вода (60:60:2:1); 2-е направление - хлороформ - ацетон - метанол - уксусная кислота - вода $(6: 8: 2: 2: 1)$. В качестве специфических обнаружителей использовали $\alpha$-нафтол.

Состав жирных кислот связанных стеринов побегов боярышника кроваво-красного (как эфиров стеринов, так и гликозидов стеринов) устанавливали методом газожидкостной хроматографии на хроматографе «Цвет 500». Компоненты идентифицировали по стандартным образцам метиловых эфиров жирных кислот и относительным временем удерживания. Количественное содержание компонентов определяли методом внутренней нормализации.

\section{Обсуждение результатов}

Из литературных источников известно, что содержание стеринов в растениях зависит от времени года. Поэтому проводились исследования по содержанию свободных и связанных стеринов в боярышнике, и установлено влияние фенологического состояния дерева на их содержание. 
Стерины присутствуют в растениях в свободном и связанном состоянии в виде эфиров и гликозидов. В настоящих исследованиях количественная оценка этих групп показана на рисунке 1.

Наибольшее количество стеринов наблюдается с наступлением периода покоя, достигая максимальной величины в декабре - январе, во время наиболее низких температур. В осеннее время понижение температуры воздуха приводило к заметному увеличению содержания стеринов в побегах боярышника. В период цветения количество стеринов в побегах достигало минимальной величины. Таким образом, выявлена характерная закономерность, в которой наблюдается наличие максимума содержания стеринов, эфиров стеринов и гликозидов в побегах боярышника кроваво-красного в зимнее время и минимума в период вегетации.

Уравнения регрессии содержания свободных стеринов и эфиров стеринов боярышника в течение годового цикла представлены следующими формулами соответственно:

$$
\begin{aligned}
& y(x)=0,2681-0,0194 \cdot x+0,0048 \cdot x^{2} \\
& y(x)=0,0564-0,0121 \cdot x+0,0018 \cdot x^{2} .
\end{aligned}
$$

Анализ исследований при изучении фитостеринов листьев боярышника кроваво-красного в процессе активной вегетации растений показал, что в период с мая по сентябрь содержание стеринов подвергалось сильным изменениям. Максимальное накопление этих веществ наблюдали в июне в период созревания. В августе в листьях найдено значительно меньше стеринов, чем в июне (рис. 2). Дальнейшее падение уровня свободных стеринов можно объяснить продолжающимся процессом их связывания с фосфолипидами.

Изучено содержание свободных и связанных стеринов в плодах боярышника. Максимальное их количество наблюдается в сентябре - октябре. Основным представителем фитостеринов в плодах боярышника кроваво-красного является $\beta$-ситостерин - $67 \%$.

По данным работы [4], содержание всех связанных форм стеринов в листе составляет немногим более 1/3 суммы стеринов. Исходя их постулата о свободных стеринах как биологических предшественниках эфиров стеринов, можно предполагать, что некоторая часть свободных стеринов постоянно переходит в связанную форму.

Анализировался жирно-кислотный состав в побегах боярышника кроваво-красного в течение года. Результаты хроматограмм представлены в таблице.

Основную долю кислот эфиров стеринов и гликозидов стеринов в побегах боярышника кровавокрасного составляют непредельные кислоты. Из полученных данных видно, что количественное соотношение предельных и непредельных кислот в ходе вегетации изменяется незначительно. Среди предельных кислот преобладают пальмитиновая и стеариновая кислоты с максимумом в весенне-летний период, так как содержание непредельных кислот повышено в осенне-зимний период. Состав кислот связанных стеринов в плодах боярышника значительно отличается от состава кислот в побегах. Анализ жирно-кислотного состава плодов боярышника показывает, что в основном преобладают непредельные кислоты, и лишь около $20 \%$ приходится на предельные кислоты. Из непредельных кислот доминируют линолевая кислота $(43 \%)$ и олеиновая $(32 \%)$.

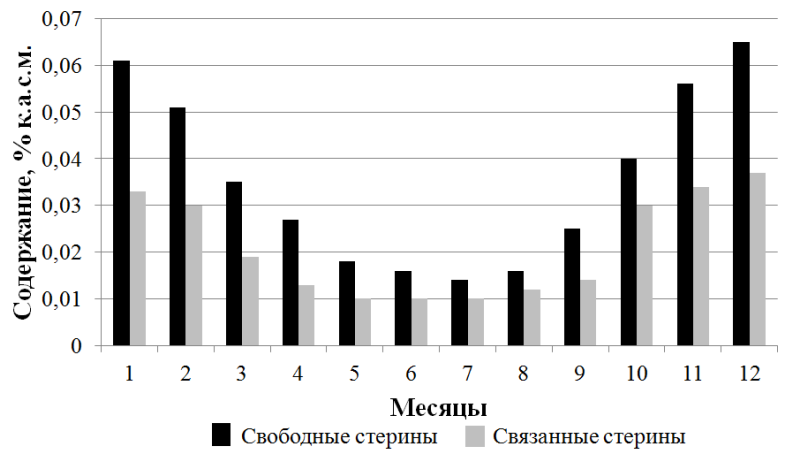

Рис.1. Динамика изменения содержания свободных и связанных стеринов в побегах боярышника кроваво-красного

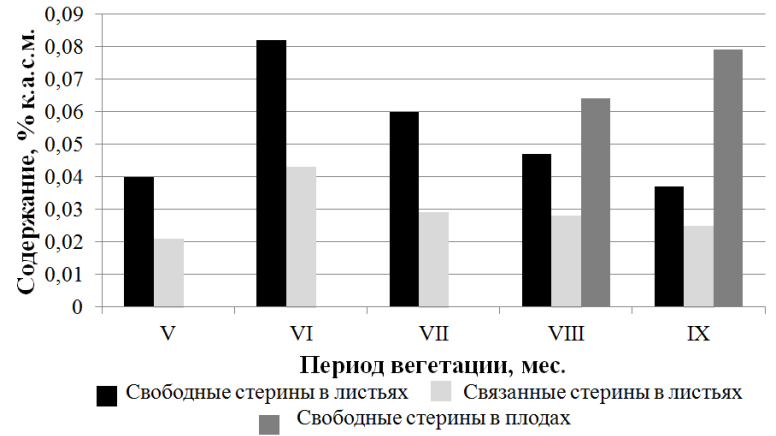

Рис. 2. Содержание свободных и связанных стеринов в листьях и плодах боярышника кроваво-красного 
Состав кислот эфиров и гликозидов стеринов в побегах боярышника кроваво-красного, \% к сумме кислот

\begin{tabular}{l|c|c|c|c|c|c|c|c}
\hline \multirow{2}{*}{\begin{tabular}{c} 
Наименование \\
\multicolumn{1}{c|}{ кислот }
\end{tabular}} & \multicolumn{2}{|c|}{ Январь } & \multicolumn{2}{c|}{ Апрель } & \multicolumn{2}{c}{ Июль } & \multicolumn{2}{c}{ Октярь } \\
\cline { 2 - 9 } & $\begin{array}{c}\text { эфиры } \\
\text { стеринов }\end{array}$ & $\begin{array}{c}\text { гликозиды } \\
\text { стеринов }\end{array}$ & $\begin{array}{c}\text { эфиры } \\
\text { стеринов }\end{array}$ & $\begin{array}{c}\text { гликозиды } \\
\text { стеринов }\end{array}$ & $\begin{array}{c}\text { эфиры } \\
\text { стеринов }\end{array}$ & $\begin{array}{c}\text { гликозиды } \\
\text { стеринов }\end{array}$ & $\begin{array}{c}\text { эфиры } \\
\text { стеринов }\end{array}$ & $\begin{array}{c}\text { гликозиды } \\
\text { стеринов }\end{array}$ \\
\hline Миристиновая & 0,26 & 0,75 & 0,33 & 1,16 & 0,24 & 0,51 & 0,32 & 0,44 \\
Пальмитиновая & 15,57 & 14,13 & 17,53 & 17,14 & 20,67 & 19,08 & 15,84 & 16,82 \\
Пальмиолеиновая & 1,21 & 6,82 & 2,16 & 4,33 & 1,21 & 3,35 & 0,36 & 2,33 \\
Стеариновая & 16,14 & 12,18 & 22,53 & 13,84 & 21,25 & 12,92 & 16,69 & 12,36 \\
Олеиновая & 13,21 & 20,34 & 14,94 & 18,92 & 16,43 & 16,95 & 15,91 & 21,56 \\
Линолевая & 16,13 & 17,85 & 14,36 & 16,26 & 14,81 & 14,93 & 18,43 & 17,98 \\
Линоленовая & 30,14 & 26,73 & 21,25 & 26,44 & 17,46 & 22,83 & 30,32 & 20,47 \\
Арахиновая & 3,24 & 1,94 & 8,24 & 5,21 & 8,26 & 8,41 & 3,96 & 3,67 \\
Бегеновая & 0,73 & 0,50 & 0,98 & 0,73 & 0,55 & 1,06 & 0,54 & 0,35 \\
Лигноцериновая & 0,67 & 0,56 & 0,94 & 0,80 & 0,71 & 0,54 & 0,52 & 0,51 \\
\hline
\end{tabular}

\section{Выводы}

Таким образом, содержание стеринов в анатомических частях боярышника кроваво-красного различно и зависит от фенологического состояния дерева. Эфиры стеринов и гликозиды стеринов содержат в своём составе предельные и непредельные кислоты, содержание которых изменяется в течение года. Стерины листьев в процессе активной вегетации растений подвергались сильным изменениям с уменьшением их количества в фазе опадения. Анализ содержания стеринов различных анатомических частей показывает влияние этих соединений на морозоустойчивость растения, уязвимость к неблагоприятным воздействиям окружающей среды. Исследования в данной области являются актуальными, так как повышенное содержание $\beta$-ситостерина в плодах может использоваться в качестве сырья для синтеза стероидных гормонов.

\section{Список литературы}

1. Кейтс М. Техника липидологии. М., 1975. 322 с.

2. Grunwald C. Sterol distribustion in intracellulaz oraganelles isolated from tobacco leaves // Plant Physiol., 1970. Vol. 45, N4. Pp. 663-666.

3. Нивицкая Г.В., Руцкая Л.А. Количественное определение липидов мембран хлоропластов // Физиология растений. 1976. Т. 23. С. 899-905.

4. Grunwald C. Functions of sterols // Phil. Trans. Roy. Soc. 1978. Vol. B284, N1002. Pp. 541-558.

Поступило в редакиию 18 апреля 2013 г.

Devyatlovskaya A.N..$^{{ }^{*}}$, Guravlyeva L.N. ${ }^{1}$, Alashkevich $U . D .^{2}$ THE STUDIED OF MATTER STEROLS IN ANATOMY PARTS OF CRATAEGUS SANGUNEA

${ }^{1}$ Lesosibirsk brunch of Siberian State University of Technology, 29, Pobeda st., Lesosibirsk, 662543 (Russia),

e-mail: devyatlovskiy@mail.ru

${ }^{2}$ Siberian Siberian State University of Technology, 82, Mira st., Kranoyarsk, 660049, (Russia),

e-mail:mapt@sibstu.kts.ru

We investigated the content of free and associated sterols in anatomy parts of the crataegus sangunea in the course of the annual cycle. The work presents the dynamics of studying changes in the content of sterols in the shoots, leaves, and fruits. It is established, that acid esters and glycosides sterols contain in its composition limits and unsaturated acids, the content of which in the course of the growing season changes.

Keywords: Sterols, glycosides, annual cycle, fatty acid, stearic acid, palmitic acid.

\section{References}

1. Keits M. Tekhnika lipidologii. [Technique lipidology]. Moscow, 1975, 322 p. (in Russ.).

2. Grunwald C. Plant Physiol., 1970, vol. 45, no. 4, pp. 663-666.

3. Nivitskaia G.V., Rutskaia L.A. Fiziologiia rastenii, 1976, vol. 23, pp. 899-905. (in Russ.).

4. Grunwald C. Phil. Trans. Roy. Soc., 1978, vol. B284, no. 1002, pp. 541-558.

\footnotetext{
* Corresponding author.
} 